\title{
PENGARUH PENGGUNAAN INTERNET TERHADAP MINAT DAN HASIL BELAJAR MATEMATIS SISWA KELAS VIII SMP NEGERI 1 KUALUH SELATAN
}

\section{THE EFFECT OF THE USE OF THE INTERNET ON THE INTEREST AND THE OUTCOMES OF MATHEMATIC LEARNING STUDENTS OF VIII CLASS SMP NEGERI 1 KUALUH SELATAN}

\author{
YUSTIKA POHAN \\ SMP Negeri 1 Kualuh Selatan, Sumatera Utara, Indonesia, email: yustikapohan@gmail.com
}

\begin{abstract}
Abstrak
Penelitian ini bertujuan untuk mengetahui pengaruh penggunaan internet terhadap minat dan hasil belajar matematis siswa kelas VIII di SMP Negeri 1 Kualuh Selatan. Penelitian ini merupakan penelitian kuantitatif jenis Ex-post Facto. Sampel penelitian ini adalah peserta didik kelas VIII SMP Negeri 1 Kualuh Selatan dengan jumlah populasi 138 siswa. Sampel dalam Penelitian ini yaitu kelas VIII-4. Validitas instrumen angket dilakukan dengan analisis butir menggunakan rumus korelasi Product Moment dan uji reliabilitas menggunakan rumus Alpha Cronbach. Teknik analisis data menggunakan uji normalitas dengan kolmogorof smirnov dan uji linieritas. Dilanjutkan dengan uji hipotesis yaitu menggunakan uji regresi linier sederhana dan uji manova. Berdasarkan hasil analisis dan pembahasan dari data penelitian diperoleh hasil bahwa ada pengaruh yang positif dan signifikan penggunaan internet terhadap minat belajar siswa kelas VIII SMP Negeri 1 Kualuh Selatan sebesar $91 \%$ dengan nilai $T_{\text {hitung }}=16,507\left(>T_{\text {tabel }}=2,052\right)$ taraf signifikan $5 \%$ dan ada pengaruh yang negatif terhadap penggunaan internet terhadap hasil belajar matematis siswa kelas VIII SMP Negeri 1 Kualuh Selatan sebesar $14 \%$. Dengan nilai $T_{\text {hitung }}=-0,611\left(<T_{\text {tabel }}=r 2,052\right)$ taraf signifikan $5 \%$. Serta terdapat pengaruh penggunaan internet terhadap minat dan hasil belajar matematis kelas VIII SMP Negeri 1 Kualuh Selatan dengan semua nilai menunjukkan nilai Sig. $(0,000)$. maka nilai Sig $(0,000)<0,05$. Kesimpulan ada pengaruh penggunaan internet terhadap minat dan hasil belajar siswa kelas VIII SMP Negeri 1 Kualuh Selatan. Saran siswa sebaiknya memanfaatkan fasilitas internet yang disediakan untuk menambah wawasan dan mengerjakan tugas yang diberikan oleh guru.
\end{abstract}

\section{Kata kunci : Penggunaan Internet, Minat Belajar, Hasil Belajar}

\begin{abstract}
This study aims to determine the effect of using the internet on the interest and learning outcomes of class VIII students at SMP Negeri 1 Kualuh Selatan. This research is a quantitative research type Ex-post Facto. The sample of this research was students of class VIII SMP Negeri 1 Kualuh Selatan with a population of 138 students. The sample in this study is class VIII-4. The validity of the questionnaire instrument was carried out by analyzing the items using the Product Moment correlation formula and the reliability testing using the Alpha Cronbach formula. The data analysis technique used the normality test with Kolmogorof Smirnov and linearity test. Followed by hypothesis testing using simple linear regression and Manova test. Based on the results of the analysis and discussion of the research data, it was found that there was a positive and significant influence of the use of the internet on the learning interest of class VIII students of SMP Negeri 1 Kualuh Selatan by $91 \%$ with a value of tcount $=16.507(>\mathrm{T}$ table $=2.052)$ with a significant level of $5 \%$ and there were the negative influence on the use of the internet on the mathematical learning outcomes of class VIII students of SMP Negeri 1 Kualuh Selatan by $14 \%$. With the value of $t=-0.611(<T$ table $=r 2.052)$ with a significant level of $5 \%$. And there is an effect of internet use on the interest and learning outcomes of class VIII of SMP Negeri 1 Kualuh Selatan with all values showing the value of Sig. $(0,000)$. then the value of Sig $(0.000)<0.05$. The conclusion is that the use of the internet has an effect on the interest and learning outcomes of class VIII students of SMP Negeri 1 Kualuh Selatan. Suggestions for students should take advantage of the internet facilities provided to add insight and do assignments given by the teacher.
\end{abstract}

Keywords: Internet Use, Learning Interest, Learning Outcomes 
Hal : $93-100$

\section{Pendahuluan}

Di era kemajuan jaman yang serba canggih saat ini, juga membuat perkembangan ilmu serta informasi dan teknologi berkembang dengan cepat [6]. Belum selesai kita memahami dan menerapkan suatu bidang ilmu, telah muncul berbagai bidang ilmu baru yang harus kita pahami serta kita ikuti perkembangannya. Dari perkembangan teknologi atau kita sebut Internet telah banyak mengubah kebiasaan ataupun pola kehidupan masyarakat dan juga seorang siswa [9]. Internet memberikan banyak kontribusi bagi siswa, dengan internet siswa dapat lebih mudah menemukan atau mencari informasi yang berhubungan dengan kegiatan belajar mengajar [1]. Siswa dapat mengakses berbagai informasi, referensi, artikel dan lain-lain dari berbagai bidang ilmu [8].

Kemajuan teknologi informasi dan telekomunikasi yang sangat pesat membuka peluang siswa untuk menjelajah berbagai data informasi di internet sehingga membuka peluang bagi siswa untuk menambah pengetahuannya sendiri dan merupakan salah satu faktor yang mempengaruhi prestasi belajar [9]. Penggunaan internet dalam pembelajaran akan sangat bermanfaat apabila digunakan dengan bijak untuk mendapatkan informasi atau materi pelajaran di sekolah [7]. Tetapi masih banyak siswa yang memanfaatkan internet bukan untuk keperluan belajar melainkan untuk game online dan chatting. Sedangkan Internet bagaikan perpustakaan dunia yang bisa di akses dengan cepat dan mudah sesuai dengan kebutuhan yang diperlukan [11].

Dengan adanya internet diharapkan menjadi sumber belajar yang baik serta memudahkan bagi siswa. Tetapi masih banyak siswa yang dalam Penggunaan internet sebagai salah satu sumber belajar yang kurang tepat sasaran, dimana siswa tersebut menggunakan internet diluar konteks pembelajaran [11]. Dengan adanya internet diharapkan menjadi sumber belajar yang baik serta memudahkan bagi siswa [5] . Tetapi masih banyak siswa yang dalam Penggunaan internet sebagai salah satu sumber belajar yang kurang tepat sasaran, dimana siswa tersebut menggunakan internet diluar konteks pembelajaran [9].

Minat dalam suatu proses belajar mengajar juga merupakan salah satu faktor terbesar dalam hasil belajar siswa. Seorang siswa akan memperoleh hasil belajar yang baik apabila siswa tersebut bersungguhsungguh dalam belajar [2]. Minat belajar muncul karena keinginan dalam diri pribadi seseorang maupun faktor yang berpengaruh dari luar. Minat belajar juga bukan hanya bergantung pada keinginan siswa tetapi juga dipengaruhi pada segala kegiatan belajar siswa seperti guru yang mengajar, sarana dan prasarana, kemampuan orang tua, bahan pelajaran, lingkungan sekolah, faktor fisik dan rohani serta metode dan strategi pembelajaran [12].

Minat belajar memiliki pengaruh terhadap hasil belajar siswa, sehingga pentingnya siswa dalam memiliki minat belajar karena minat belajar seseorang berkaitan dengan tujuan. Seorang siswa yang memiliki minat belajar yang tinggi maka siswa tersebut akan berusaha dengan sungguh-sungguh dalam belajar untuk mencapai tujuannya [3].

Hasil belajar siswa merupakan usaha yang telah dicapai. Hasil belajar merupakan suatu kegiatan yang telah dikerjakan dan dilakukan dengan senang hati yang dipeoleh dengan usaha yang baik secara individual maupun kelompok dalam kegiatan tertentu [10] . Dalam kegiatan tersebut tidak semudah dibayangkan untuk mendapatkan hasil belajar yang baik. Tetapi penuh dengan perjuangan dan berbagai tantangan yang harus dihadapi.

Dalam belajar pasti mempunyai sebuah tujuan untuk mencapai suatu yang diinginkan yaitu memperoleh pengalaman dan pengetahuan. Banyak cara atau faktor yang dapat berpengaruh dalam memperoleh hasil belajar yang bagus. salah satunya adalah penggunaan internet [4].

Dengan mengguanakan internet seorang siswa dapat mengakses berbagai informasi dan pengetahuan. Namun internet bisa berdampak buruk terhadapa prestasi belajar siswa jika tidak digunakan dengan bijak [14]. Selain penggunaan internet yang berpengaruh terhadap hasil belajar siswa, Minat belajar juga dapat mempengarugi hasil belajar siswa. Minat belajar siswa yang rendah akan mengakibatkan siswa tidak tertarik dalam mengukuti suatu kegiatan yang berada di sekolah sehingga akan menimbulkan hasil belajar siswa yang menurun.

\section{Metode Penelitian}

Penelitian ini menggunakan jenis penelitian expost facto. Penelitian ini ditujukan untuk meneliti peristiwa yang telah terjadi dan kemudian merunut ke belakang tentang faktor-faktor yang menyebabkan timbulnya kejadian tersebut [13].. Berdasarkan keterangan tersebut penelitian ini tidak memberikan perlakuan khusus terhadap variabel yang akan diteliti, tetapi hanya mengungkap fakta-fakta yang ada berdasarkan pengukuran gejala pada responden. Sedangkan penelitian ini bila ditinjau dari sifat data dan cara pengolahannya merupakan penelitian kuantitatif. Waktu penelitian ini dilaksanakan pada bulan juli 2020. Subjek dalam penelitian ini adalah seluruh siswa kelas VIII SMP N 1 Kualuh Selatan dengan jumlah 138 siswa. Sampel dalam penelitian ini adalah siswa kelas VIII-4 SMP Negeri 1 Kulauh Selatan Tahun Aaran 2019/2020 
yang berjumlah 29 siswa. Dimana teknik pengambilan sampel yaitu dengan menggunakan Cluster Random Sampling.

Adapun metode pengumpulan data dalam penelitian ini adalah melalui angket dan tes uraian yang disesuaikan dengan kurikulum yang berlaku, dalam metode tersebut tentu isesuaikan dengan model pembelajaran penelitian yang digunakan. Untuk mendapatkan data yang diperlukan dalam penelitian ini penulis menggunakan instrumen (perintah/petunjuk). Adapun angket yang gunakan untuk penelitian ini berjumlah 40 soal ( 20 butir soal penggunaan internet dan 20 butir soal minat belajar) dan tes uraian berjumlah 5 soal tentang bangun ruang sisi datar.

\section{Hasil Penelitian dan Pembahasan}

\section{Hasil Penelitian}

\section{a. Uji Normalitas}

Uji normalitas ini dimaksudkan untuk mengetahui bahwa distribusi penelitian tidak menyimpang secara signifikan dari distribusi data normal.

Tabel 1. Hasil Uji Normalitas Penggunaan Internet terhadap Minat Belajar

One-Sample Kolmogorov-Smirnov Test

\begin{tabular}{lll}
\hline$N$ & & Unstandardized Residual \\
\hline Normal Parameters & & 29 \\
& Mean &, 0000000 \\
\cline { 2 - 3 } & Std. Deviation & 3,05135290 \\
\hline Most Extreme Differences & Absolute &, 094 \\
\cline { 2 - 3 } & Positive &, 094 \\
\cline { 2 - 3 } & Negative &,- 059 \\
\hline Test Statistic & &, 094 \\
\hline Asymp. Sig. (2-tailed) & &, $200^{\mathrm{c}, \mathrm{d}}$ \\
\hline
\end{tabular}

a. Test distribution is Normal.

Tabel 2. Hasil Uji Normalitas Penggunaan Internet terhadap Hasil Belajar

One-Sample Kolmogorov-Smirnov Test

\begin{tabular}{lll}
\hline $\mathrm{N}$ & & Unstandardized Residual \\
\hline Normal Parameters & & 29 \\
\hline Most Extreme & Mean &, 0000000 \\
\cline { 2 - 3 } & Std. Deviation & 11,13419023 \\
\hline Test Statistic & Absolute &, 120 \\
\cline { 2 - 3 } & Positive &, 115 \\
\cline { 2 - 3 } & Negative &,- 120 \\
\hline Asymp. Sig. (2-tailed) & &, 120 \\
\hline
\end{tabular}

a. Test distribution is Normal.

Dari hasil pengujian di atas menunjukkan tabel One-Sample Kolmogrov-Smirnov Text diperoleh angka Asymp Sig.(2-tailed). Kriteria pengambilan keputusan yaitu jika Signifikansi > 0,05 maka distribusi normal, dan jika Signifikansi $<0,05$ maka data berdistribusi tidak normal. Dari hasil di atas dapat ditarik kesimpulan bahwa uji kolomorov smirnov menunjukkan bahwa residual data yang didapat tersebut mengikuti distribusi normal, berdasarkan hasil output menunjukkan nilai signifikan pada 0,200 >0,05 dan 0,200>0,05. Dengan demikian residual data berdistribusi normal.

\section{b. Uji Linieritas} penelitian.

Uji linearitas merupakan suatu prosedur yang digunakan untuk mengetahui status linier atau tidaknya 
Tabel 3. Hasil Perhitungan Linieritas

\begin{tabular}{|c|c|c|c|c|c|c|c|}
\hline & & & $\begin{array}{l}\text { Sum of } \\
\text { Squares }\end{array}$ & Df & $\begin{array}{l}\text { Mean } \\
\text { Square }\end{array}$ & $\mathrm{F}$ & \\
\hline \multirow{5}{*}{$\begin{array}{l}\text { MINAT BELAJAR } \\
\text { PENGGUNAAN INTERNET }\end{array}$} & \multirow{3}{*}{$\begin{array}{l}\text { Between } \\
\text { Groups }\end{array}$} & (Combined) & 2809,425 & 9 & 312,158 & 31,326 &, 000 \\
\hline & & Linearity & 2738,057 & 1 & 2738,057 & 274,770 & ,000 \\
\hline & & $\begin{array}{l}\text { Deviation } \\
\text { from } \\
\text { Linearity }\end{array}$ & 71,368 & 8 & 8,921 & ,895 &, 539 \\
\hline & \multicolumn{2}{|c|}{ Within Groups } & 189,333 & 19 & 9,965 & & \\
\hline & \multicolumn{2}{|c|}{ Total } & 2998,759 & 28 & & & \\
\hline \multirow{5}{*}{$\begin{array}{l}\text { HASIL BELAJAR * } \\
\text { PENGGUNAAN INTERNET }\end{array}$} & \multirow{3}{*}{$\begin{array}{l}\text { Between } \\
\text { Groups }\end{array}$} & (Combined) & 1318,424 & 9 & 146,492 & 1,262 & ,318 \\
\hline & & Linearity & 52,973 & 1 & 52,973 & ,456 &, 507 \\
\hline & & $\begin{array}{l}\text { Deviation } \\
\text { from } \\
\text { Linearity }\end{array}$ & 1265,451 & 8 & 158,181 & 1,363 & ,274 \\
\hline & \multicolumn{2}{|c|}{ Within Groups } & 2205,714 & 19 & 116,090 & & \\
\hline & \multicolumn{2}{|c|}{ Total } & 3524,138 & 28 & & & \\
\hline
\end{tabular}

Berdasarkan hasil data di atas maka dapat disimpulkan bahwa:

1) Pada linieritas penggunaan internet $(X)$ dengan minat belajar $(Y 1)$ tingkat signifikansinya $0,539<0,05$ dan Fhitung < Ftabel $(0,895<4,13)$. Dengan demikian menunjukkan bahwa terdapat hubungan linear yang signifikan antara penggunaan internet $(X)$ dengan variabel minat belajar $(\mathrm{Y} 1)$.

2) Pada linieritas penggunaan internet $(X)$ dengan hasil belajar (Y2) tingkat signifikansinya $0,247<0,05$ dan Fhitung < Ftabel $(1,363<4,13)$. Dengan demikian menunjukkan bahwa terdapat hubungan linear yang signifikan antara variabel penggunaan internet $(X)$ dengan variabel hasil belajar (Y2).

c. Uji Hipotesis

1. Hasil Uji Hipotesis Pertama

Adapun hasil uji regresi linier sederhana yang diuji tiap variabel sebagai berikut:

Tabel 4. Hasil Uji Regresi Linier Sederhana Variabel Penggunaan Interenet terhadap Minat Belajar

\begin{tabular}{|c|c|c|c|c|c|c|}
\hline \multicolumn{7}{|c|}{ Coefficients $^{a}$} \\
\hline \multirow{2}{*}{\multicolumn{2}{|c|}{ Model }} & \multicolumn{2}{|c|}{$\begin{array}{l}\text { Unstandardized } \\
\text { Coefficients }\end{array}$} & \multirow{2}{*}{$\begin{array}{l}\text { Standardized } \\
\text { Coefficients } \\
\text { Beta }\end{array}$} & \multirow[b]{2}{*}{$t$} & \multirow[b]{2}{*}{ Sig. } \\
\hline & & $\mathrm{B}$ & Std. Error & & & \\
\hline \multirow[t]{2}{*}{1} & (Constant) & 2,646 & 2,975 & & ,889 & ,382 \\
\hline & $\begin{array}{l}\text { PENGGUNAAN } \\
\text { INTERNET }\end{array}$ & 1,217 &, 074 & ,954 & 16,507 & ,000 \\
\hline
\end{tabular}

a. Dependent Variable: MINAT BELAJAR

Berdasarkan tabel Coefficients, diketahui bahwa nilai koefisien regresi variabel penggunaan internet (X) adalah sebesar 1,217 bernilai positif (+), sehingga dapat dikatakan bahwa penggunaan internet berpengaruh positif terhadap minat belajar. Selanjutnya untuk mengetahui apakah pengaruh tersebut signifikan atau tidak, dapat dilihat dengan apabila besarnya nilai thitung $>t_{\text {tabel }}(16,507>2,052)$ atau jika $t_{\text {sig }}<\alpha(0,000<$ $0,05)$ maka $\mathrm{H}_{0}$ ditolak dan $\mathrm{H}_{\mathrm{a}}$ diterima. Dengan demikian dapat diartikan bahwa ada pengaruh yang signifikansi antara variabel penggunaan internet terhadap minat belajar. 
Hal : $93-100$

Tabel 5. Hasil Koefisien Determinasi Variabel Penggunaan Internet terhadap Minat Belajar

\section{Model Summary}

\begin{tabular}{ll|l|l|l} 
Model & $\mathrm{R}$ & R Square & Adjusted R Square & Std. Error of the Estimate \\
\hline 1 &, $954^{\mathrm{a}}$ &, 91 &, 907 & 3,164 \\
\end{tabular}

a. Predictors: (Constant), PENGGUNAAN INTERNET

Berdasarkan tabel model summary dapat diketahui bahwa penggunaan internet memiliki kontribusi sebesar $91 \%$ terhadap minat belajar.

2. Hasil Uji Hipotesis Kedua

Adapun hasil uji regresi linier sederhana yang diuji tiap variabel sebagai berikut:

Tabel 5. Hasil Uji Regresi Linier Sederhana Variabel Penggunaan Interenet terhadap Minat Belajar

\section{Coefficients $^{\mathrm{a}}$}

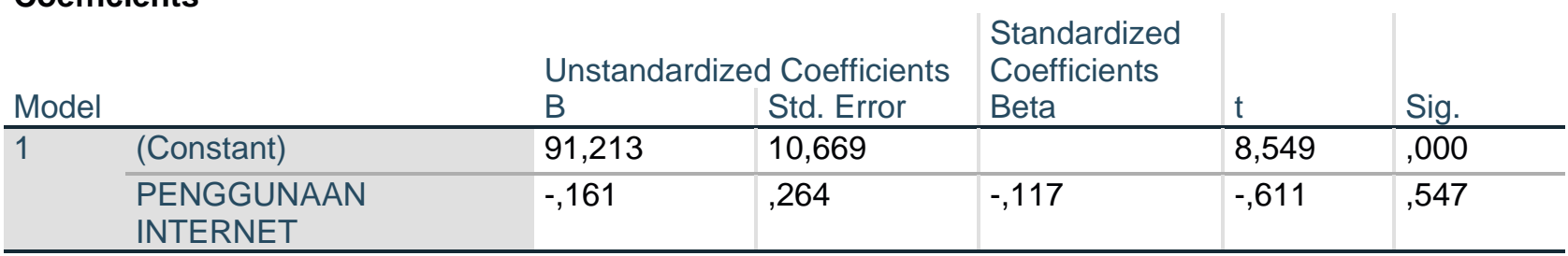

a. Dependent Variable: HASIL BELAJAR

Berdasarkan tabel Coefficients, diketahui bahwa nilai koefisien regresi variabel penggunaan internet (X) adalah sebesar $-0,161$ bernilai positif (-), sehingga dapat dikatakan bahwa penggunaan internet berpengaruh negatif terhadap hasil belajar.

Selanjutnya untuk mengetahui apakah pengaruh tersebut signifikan atau tidak, dapat dilihat dengan apabila besarnya nilai thitung $>$ ttabel $(-0,611>2,052)$ atau jika tsig $<\alpha(0,547<0,05)$ maka $\mathrm{HO}$ diterima dan Ha ditolak. Dengan demikian dapat diartikan bahwa tidak ada pengaruh yang signifikansi antara variabel penggunaan internet terhadap hasil belajar matematis siswa.

Tabel 6. Hasil Koefisien Determinasi Variabel Penggunaan Internet terhadap Hasil Belajar

\section{Model Summary}

\begin{tabular}{ll|l|l|l} 
Model & $\mathrm{R}$ & $\mathrm{R}$ Square & Adjusted R Square & Std. Error of the Estimate \\
\hline 1 &, $117^{\mathrm{a}}$ &,- 014 & 11,347 \\
& & & \\
\hline
\end{tabular}

a. Predictors: (Constant), PENGGUNAAN INTERNET

Berdasarkan tabel model summary dapat diketahui bahwa kompetensi kepribadian guru memiliki kontribusi sebesar $14 \%$ terhadap hasil belajar matematis siswa.

\section{Uji Hipotesis Ketiga}

Pengujian hipotesis menggunakan Uji MANOVA dengan variabel independennya penggunaan internet (X) terhadap dua variabel dependent yaitu minat belajar (Y1) dan hasil belajar (Y2). Adapun hasil dari uji manova sebagai berikut:

Tabel 7. Hasil Uji Multivariate Tests

\section{Multivariate Tests $^{\mathrm{a}}$}

\begin{tabular}{lll|l|l|l|l} 
Effect & & Value & F & Hypothesis df & Error df & Sig. \\
\hline Intercept & Pillai's Trace &, 777 & $45,213^{\mathrm{b}}$ & 2,000 & 26,000 &, 000 \\
\cline { 2 - 7 } & Wilks' Lambda & 223 & $45,213^{\mathrm{b}}$ & 2,000 & 26,000 &, 000 \\
\hline
\end{tabular}


Hal : $93-100$

\begin{tabular}{ll|l|l|l|l|l}
\hline & Hotelling's Trace & 3,478 & $45,213^{\mathrm{b}}$ & 2,000 & 26,000 &, 000 \\
\cline { 2 - 8 } penggunaan_internet & Roy's Largest Root & 3,478 & $45,213^{\mathrm{b}}$ & 2,000 & 26,000 &, 000 \\
\hline & Pillai's Trace &, 913 & $136,731^{\mathrm{b}}$ & 2,000 & 26,000 &, 000 \\
\cline { 2 - 9 } & Wilks' Lambda &, 087 & $136,731^{\mathrm{b}}$ & 2,000 & 26,000 &, 000 \\
\cline { 2 - 9 } & Hotelling's Trace & 10,518 & $136,731^{\mathrm{b}}$ & 2,000 & 26,000 &, 000 \\
\cline { 2 - 8 } & Roy's Largest Root & 10,518 & $136,731^{\mathrm{b}}$ & 2,000 & 26,000 &, 000 \\
\hline
\end{tabular}

a. Design: Intercept + penggunaan_internet

b. Exact statistic

Tabel multivariate Tests kolom Sig pada garis penggunaan internet, semua menunjukkan nilai Sig $(0,000)$. maka nilai Sig $(0,000)<0,05$ tersebut mengidentifikasikan $\mathrm{H}_{0}$ ditolak dan $\mathrm{H}_{\mathrm{a}}$ diterima sehingga dapat disimpulkan.

\section{Pembahasan}

Penelitian ini dilakukan dengan menggunakan angket dan tes. Dimana Kuesioner berjumlah 40 (20 dari variable penggunaan internet $(\mathrm{X})$ dan 20 dari variabel minat belajar (Y1)) dan tes 5 soal (dari variabel $\mathrm{Y} 2$ ). Berdasarkan hasil uji hipotesis berikut diperoleh hasil sebagai berikut :

1) Penggunaan internet terhadap minat belajar

\begin{tabular}{|l|l|l|l|l|l|}
\hline & $\mathbf{R}$ & $\mathbf{R}^{2}$ & $\mathbf{t}$ & $\mathbf{T}_{\mathbf{0}, 05}(\mathbf{2 9})$ & Sig. \\
\hline $\begin{array}{l}\text { Penggunaan Internet } \\
\text { terhadap Minat Belajar siswa }\end{array}$ & 0,954 & 0,91 & 16,057 & 2,052 & 0,000 \\
\hline
\end{tabular}

Berdasarkan hasil analisis data dengan menggunakan SPSS menunjukkan R merupakan suatu cara atau metode untuk mengukur hubungan antara variable bebas dan variable terikat dalam waktu yang bersamaan. Dari penghitungan analisa regresi linier antara penggunaan internet (X) dengan minat belajar (Y1) diperoleh nilai $\mathrm{R}$ atau Multiple $\mathrm{R}$ sebesar 0,954.

Sedangkan Koefisien determinasi $\left(R^{2}\right)$ menunjukkan tingkat ketetapan garis regresi. Garis regresi digunakan untuk menjelaskan proporsi dari ragam minat belajar siswa (Y1) yang diterangkan oleh variabel independennya.

Berdasarkan hasil analisis data dengan menggunakan SPSS menunjukkan $R^{2}$ sebesar 0,91 . Nilai tersebut berarti $91 \%$ perubahan pada variabel prestasi belajar $(\mathrm{Y})$ dapat diterangkan oleh variabel penggunaan internet $(X)$, sedangkan $9 \%$ dijelaskan oleh faktor lain.

Pengujian signifikansi bertujuan untuk mengetahui signifikansi pengaruh penggunaa internet (X) terhadap minat belajar (Y1). Uji signifikansi menggunakan uji T. Berdasarkan hasil uji $\mathrm{T}$ diperoleh nilai $\mathrm{T}$ hitung sebesar 16,057. Jika dibandingkan dengan nilai $\mathrm{T}_{\text {tabel }}$ sebesar 2,052 pada taraf signifikansi $5 \%$ maka nilai $\mathrm{T}_{\text {hitung }}$ $>\mathrm{T}_{\text {tabel }}$ sehingga hipotesis pertama diterima. Hal ini berarti bahwa terdapat pengaruh positif penggunaan internet terhadap minat belajar siswa kelas VIII di SMA Negeri 1 Kualuh Selatan.

2) Penggunaan internet terhadap hasil belajar

\begin{tabular}{|l|l|l|l|l|l|}
\hline & $\mathbf{R}$ & $\mathbf{R}^{2}$ & $\mathbf{t}$ & $\mathbf{T}_{\mathbf{0 , 0 5}}(\mathbf{2 9})$ & Sig. \\
\hline $\begin{array}{l}\text { Penggunaan Internet } \\
\text { terhadap hasil Belajar siswa }\end{array}$ & 0,117 & 0,14 & $-0,611$ & 2,052 & 0,547 \\
\hline
\end{tabular}

Berdasarkan hasil analisis data dengan menggunakan SPSS menunjukkan R merupakan suatu cara atau metode untuk mengukur hubungan antara variable bebas dan variable terikat dalam waktu yang bersamaan. Dari penghitungan analisa regresi linier antara penggunaan internet (X) dengan minat belajar (Y1) diperoleh nilai $\mathrm{R}$ atau Multiple R sebesar 0,117.

Sedangkan Koefisien determinasi $\left(R^{2}\right)$ menunjukkan tingkat ketetapan garis regresi. Garis regresi digunakan untuk menjelaskan proporsi dari ragam minat belajar siswa (Y1) yang diterangkan oleh variabel independennya. Berdasarkan hasil analisis data dengan menggunakan SPSS menunjukkan $\mathrm{R}^{2}$ sebesar 0,14 . Nilai tersebut berarti $14 \%$ perubahan pada variabel prestasi belajar $(\mathrm{Y})$ dapat diterangkan oleh variabel penggunaan internet $(\mathrm{X})$, sedangkan $86 \%$ dijelaskan oleh faktor lain. 
Hal : $93-100$

Pengujian signifikansi bertujuan untuk mengetahui signifikansi pengaruh penggunaa internet (X) terhadap minat belajar (Y1). Uji signifikansi menggunakan uji T. Berdasarkan hasil uji $\mathrm{T}$ diperoleh nilai $\mathrm{T}$ hitung sebesar -6,11. Jika dibandingkan dengan nilai $T_{\text {tabel }}$ sebesar 2,052 pada taraf signifikansi $5 \%$ maka nilai $T_{\text {hitung }}>$ $T_{\text {tabel }}$ sehingga hipotesis pertama ditolak. Hal ini berarti bahwa terdapat pengaruh negatif penggunaan internet terhadap hasil belajar siswa kelas VIII di SMA Negeri 1 Kualuh Selatan.

3) Penggunaan internet terhadap minat dan hasil belajar matematis siswa

Pengujian hipotesis menggunakan Uji MANOVA dengan variabel independennya penggunaan internet (X) terhadap dua variabel dependent yaitu minat belajar (Y1) dan hasil belajar (Y2). Tabel multivariate Tests kolom Sig pada garis penggunaan internet, semua menunjukkan nilai Sig $(0,000)$. maka nilai Sig $(0,000)<0,05$ tersebut mengidentifikasikan $\mathrm{H}_{0}$ ditolak dan $\mathrm{H}_{a}$ diterima sehingga dapat disimpulkan bahwa ada pengaruh penggunaan internet terhadap minat dan hasil belajar matematis kelas VIII-4 SMP N.1 Kualuh Selatan.

\section{Kesimpulan}

Berdasarkan hasil penelitian dan pembahasan dapat diambil kesimpulan, antara lain:

1. Terdapat pengaruh yang positif dan signifikan penggunaan internet terhadap minat belajar siswa kelas VIII SMP Negeri 1 Kualuh Selatan yang ditunjukan melalui besarnya sumbangan pengaruh penggunaan internet terhadap minat belajar tersebut adalah 0,910 atau sebesar 91\%. Dengan menggunakan uji $\mathrm{T}$ pada taraf signifikansi 5\%. Hasil perhitungan diperoleh harga $\mathrm{T}_{\text {hitung }}$ sebesar 16,507 dan $\mathrm{T}_{\text {tabel }}$ sebesar 2,052 sehingga dapat disimpulkan bahwa penggunaan internet memberikan pengaruh yang positif dan signifikan terhadap minat belajar siswa kelas VIII SMP Negeri 1 Kualuh Selatan.

2. Terdapat pengaruh yang negatif terhadap penggunaan internet terhadap hasil belajar matematis siswa

3. Berdasarkan hasil penelitian dengan menggunakan uji Manova diperoleh Signifikan penggunaan internet semua menunjukkan nilai Sig. (0,000). maka nilai Sig $(0,000)<0,05$ tersebut mengidentifikasikan bahwa ada pengaruh penggunaan internet terhadap minat dan hasil belajar matematis kelas VIII SMP N.1 Kualuh Selatan.

\section{Daftar Pustaka}

[1] Arsyad. Azhar. 2015. Media Pembelajaran. Rajawali Press : Jakarta.

[2] Devi Arisanti, Mhd. Subhan. 2018. "Pengaruh Penggunaan Media Internet Terhadap Minat Belajar Siswa Muslim di SMP kota Pekanbaru”, Volume 3. Nomor 2 .

[3] Erlando. 2016. "Pengaruh Minat Belajar Terhadap Prestasi Belajar Matematika”, Volume 6. Nomor 3543.

[4] Fenny, dkk. 2018. "Pengaruh Pemanfaatan Internet Sebagai Sumber Belajar dan Kemandirian Belajar Terhadap Prestasi Belajar Mahasiswa Pendidikan Ekonomi FKIP UNS Angkatan Tahun 2017', Volume 4. Nomor 2.

[5] Fitri S. 2017. "Dampak Positif dan Negatif Sosial Media Terhadap Perubahan Anak. Naturalistic”, Volume 1. Nomor 2.

[6] Hamzah B. Uno, Nina Lamatenggo. 2017. Teknologi Komunikasi dan Informasi Pembelajaran, Bumi Aksara: Jakarta

[7] Khafid Ismail. 2015. "Pengaruh Penggunaan Internet Tehadap Hasil Belajar IPS Peserta Didik Kelas X SMK Nurul Huda Sukaraja Oku Timur”, Volume 1. Nomor 1. Februari 2017.

[8] Mujib, Muhammad. 2017. Pengaruh Penggunaan Internet Terhadap hasil Belajar Siswa Sekolah Menengah Atas di Kota Yogyakarta. Skripsi. Universitas Islam Negeri Sunan kalijaga. Yogyakarta.

[9] Mudiyanah. 2015. Pengaruh Pemanfaatan Internet Sebagai sumber Belajar Geografi Terhadap Hasil Belajar Siswa. Skripsi. Jakarta : Ilmu Tarbiyah dan Keguruan Universitas Islam Negeri Syarif Hidayatullah. 
Hal : $93-100$

[10] Ningsih, S. W., \& Irmayanti, R. M. A. 2019. Pengaruh Pembelajaran Dengan Pendekatan Terbuka (Open Ended Approach) Dan Jenis Kelamin Terhadap Hasil Tes Belajar Matematika Pada Kelas Viii Smp Negeri 6 Torgamba. Jurnal Berkala Mahasiswa, 1(1), 31-38.

[11] Normi, dkk. 2014. "Pengaruh Pemanfaatan Internet Terhadap Hasil Belajar Geografi Siswa Kelas XII IPS MAN 2 Kandangan", Volume 3. Nomor 4. Juli 2016.

[12] Slameto. 2015. Belajar dan Faktor-faktor yang mempengaruhinya. Rineka Cipta: Jakarta.

[13] Sugiyono. 2016. Statistika untuk Penelitian. Bandung: Alfabeta..

[14] Warsita, Bambang. 2014. Peran Profesi Pengembanagan Teknologi Pembelajaran di Sekolah dalam Mensukseskan Pelaksanaan Kurikulum 2013. Jakarta : Pustekkom Kemdikbud, Jurnal Teknodik. Volume 18. Nomor 2, Agustus 2014. 